University of South Florida

DIGITAL COMMONS

Digital Commons @ University of

@ UNIVERSITY OF SOUTH FLORIDA

South Florida

Marine Science Faculty Publications

College of Marine Science

$9-1984$

\title{
Sr Isotopic Variations along the Juan de Fuca Ridge
}

Jacqueline Eaby

U.S. Geological Survey, jdixon@usf.edu

David A. Clague

U.S. Geological Survey

John R. Delaney

University of Washington

Follow this and additional works at: https://digitalcommons.usf.edu/msc_facpub

Part of the Life Sciences Commons

\section{Scholar Commons Citation}

Eaby, Jacqueline; Clague, David A.; and Delaney, John R., "Sr Isotopic Variations along the Juan de Fuca Ridge" (1984). Marine Science Faculty Publications. 1321.

https://digitalcommons.usf.edu/msc_facpub/1321

This Article is brought to you for free and open access by the College of Marine Science at Digital Commons @ University of South Florida. It has been accepted for inclusion in Marine Science Faculty Publications by an authorized administrator of Digital Commons @ University of South Florida. For more information, please contact digitalcommons@usf.edu. 


\title{
Sr Isotopic Variations Along the Juan de Fuca Ridge
}

\author{
Jacqueline Eaby and David A. Clague \\ U.S. Geological Survey, Menlo Park, California
}

John R. Delaney

Oceanography Department, University of Washington, Seattle

\begin{abstract}
Sr isotopic ratios of 39 glass and microcrystalline basalt samples along the Juan de Fuca Ridge and 1 glass sample from Brown Bear Seamount are at the lower end of the range for normal mid-oceanic ridge basalt (MORB); the average ${ }^{87} \mathrm{Sr} /{ }^{86} \mathrm{Sr}$ ratio is $0.70249 \pm 0.00014(2-\sigma)$. Although subtle variations exist along strike of the ridge, the $\mathrm{Sr}$ isotope data do not show systematic variation relative to the proposed Cobb Hotspot. The isotopic data are inconsistent with an enriched mantle-plume origin for the CobbEickelberg Seamount chain, as has been proposed for Iceland, the Azores, and the Galapagos spreading center. Sr isotopic ratios of samples collected north and south of the Cobb offset are identical, although minor element ratios indicate that these regions have chernically distinct mantle sources. These distinct mantle sources may not have been separated long enough to develop isotopic differences.
\end{abstract}

\section{INTRODUCTION}

The hotspot model proposed by Wilson [1965] and Morgan [1973] explains the origin of linear seamount chains as the result of movement of lithospheric plates over mantle plumes. The Cobb-Eickelberg Seamount chain, in the northeast Pacific, trends northwestward from the Juan de Fuca Ridge and is interpreted to have a hotspot origin. A seamount at approximately lat $46^{\circ} \mathrm{N}$ on the axis of the Juan de Fuca Ridge (axial seamount) is coincident with the intersection of the CobbEickelberg Seamount chain and the ridge; it is thought to be the site of present hotspot activity, herein referred to as the Cobb Hotspot [Vogt and Johnson, 1975].

Detailed studies of other mid-oceanic ridge/hotspot systems, such as Iceland [Hart et al., 1973; Schilling, 1973, 1975a], the Azores [White et al., 1975, 1976; Schilling, 1975b], and the Galapagos spreading center [Schilling et al., 1982a; Verma and Schilling, 1982] showed that basalt erupted along deep midoceanic ridge segments (normal MORB) differs from basalt erupted along topographic highs associated with islands astride the ridge (enriched MORB). Normal MORB is characterized by low concentrations of incompatible elements; light rare earth element depleted patterns; high $\mathrm{K} / \mathrm{Ba}, \mathrm{K} / \mathbf{R b}$, and $\mathrm{Zr} / \mathrm{Nb}$ ratios; low ${ }^{87} \mathrm{Sr} /{ }^{86} \mathrm{Sr}$ ratios; and high ${ }^{143} \mathrm{Nd} /{ }^{144} \mathrm{Nd}$ ratios [White et al., 1975; DePaolo and Wasserburg, 1976]. These chemical characteristics are consistent with those of basalt derived from mantle source regions depleted by previous melting events [Kay et al., 1970]. Enriched MORB, which has chemical affinities to oceanic island tholeiites, differs from normal MORB by having higher concentrations of incompatible elements; rare earth element patterns more enriched in the light elements; lower $K / B a, K / R b$, and $\mathrm{Zr} / \mathrm{Nb}$ rátios; higher ${ }^{87} \mathrm{Sr} /{ }^{86} \mathrm{Sr}$ ratios; and lower ${ }^{143} \mathrm{Nd} /{ }^{144} \mathrm{Nd}$ ratios than normal MORB [Bryan et al., 1976; White and Bryan, 1977; O'Nions et al., 1977]. Schilling [1973, $1975 b$ ] and Schilling et al. [1982a] propose that enriched MORB is generated from a nondepleted mantle source. $Z$ indler et al. [1982] propose a third chemically independent mantle component, possibly related to recycled oceanic crust,

This paper is not subject to U.S. copyright. Published in 1984 by the American Geophysical Union.

Paper number 4B0708. characterized by high ${ }^{206} \mathrm{~Pb} /{ }^{204} \mathrm{~Pb}$, low ${ }^{87} \mathrm{Sr} /{ }^{86} \mathrm{Sr}$, and high ${ }^{143} \mathrm{Nd} /{ }^{144} \mathrm{Nd}$. Geochemical variations of lavas along hotspot/ ridge systems are interpreted to be the result of mixing between enriched and normal MORB end-members [Schilling, 1975a; Schilling et al., 1982a].

The objective of this study is to present new $\mathrm{Sr}$ isotopic data for lavas dredged from the Juan de Fuca Ridge and to use these data to evaluate the mantle source characteristics of the Cobb Hotspot.

\section{Geologic Setting}

The Juan de Fuca Ridge, which extends $500 \mathrm{~km}$ from the Blanco Fracture Zone to the Sovanco Fracture Zone (Figure 1 ), is a spreading center of moderate rate, $30 \mathrm{mma}^{-1}$ between the Pacific and Juan de Fuca plates. Morgan [1973] proposed the existence of a hotspot on the Juan de Fuca Ridge to explain the northwest trending linear seamount chain including Brown Bear, Cobb, and Eickelberg seamounts. K-Ar ages from Horton Seamount, located near the northwest end of the seamount chain, indicate that the Cobb Hotspot has been a zone of high volcanic productivity for at least $20 \mathrm{Ma}$ [T $\mathrm{Turner}$ et al., 1980].

There are four morphologically distinct segments of the Juan de Fuca Ridge (Figure 2): (1) A 90-km-long, linear, symmetrical southern ridge segment north of the Blanco Fracture Zone; (2) a 140-km-long complexly disturbed centrąl segment, recently offset approximately $20 \mathrm{~km}$ west of the magnetic axis of symmetry, which includes the axial seamount; (3) another 90-km-long, linear, symmetrical northern ridge segment extending northward to the Cobb offset (the tip of a northward propagating rift [Johnson et al., 1983]); and (4) the ridge north of the Cobb offset, referred to as the Endeavor Ridge [Delaney et al., 1982].

Basalt collected south of the Cobb offset (regions 1-3) is predominantly aphyric olivine- to quartz-normative tholeiite slightly to distinctly enriched in iron and titanium compared with normal MORB. Regional variations of $\mathrm{FeO}^{*}$ (total iron calculated as $\mathrm{FeO}$ ) are plotted as a function of latitude in Figure 3. Ferrobasalt ( $>10 \% \mathrm{FeO}^{*}$ ) is particularly abundant at the southern end of region 1 , and $20-30 \mathrm{~km}$ south of the Cobb offset. The maximum iron and titanium enrichment in the lavas occurs behind zones identified as propagating rifts in 


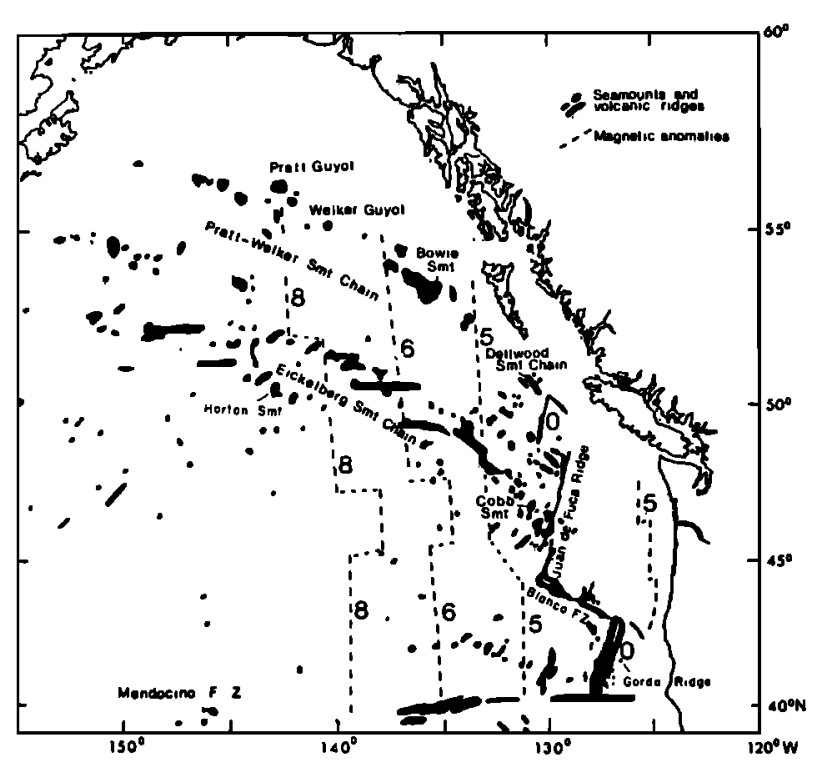

Fig. 1. Seamount and ridge distribution in the northeast Pacific Ocean. The youngest seamount of the Cobb-Eickelberg Seamount chain occurs at the intersection of the seamount chain and the Juan de Fuca Ridge. Figure modified from Barr [1974].

both regions [Hey and Wilson, 1982; Delaney et al., 1981; Johnson et al., 1983]. The petrologic diversity of lavas in regions 1-3 may be the result of variable degrees of fractional crystallization [Clague and Bunch, 1976] in magma chambers spatially associated with propagating rifts [Sinton et al., 1983]. Vogt and Byerly [1976] postulated that the iron and titanium enrichment could result from fractional crystallization in a subaxial conduit transporting magma longitudinally away from the hotspot.

Basalt from region 4 is chemically distinct from basalt south of the Cobb offset. The lavas are not unusually enriched in iron and titanium but are enriched in $\mathrm{K}_{2} \mathrm{O}$ (up to $0.56 \mathrm{wt} \%$ ), $\mathrm{Na}_{2} \mathrm{O}$ (up to 3.36 wt \%), and $\mathrm{SiO}_{2}$ (up to $52.5 \mathrm{wt} \%$ ). The $\mathrm{P}_{2} \mathrm{O}_{5} / \mathrm{K}_{2} \mathrm{O}$ ratios range from 0.5 to 0.8 compared with $\mathrm{P}_{2} \mathrm{O}_{5}$ $/ \mathrm{K}_{2} \mathrm{O}$ ratios of $>1.0$ for lavas south of the Cobb offset (J.R. Delaney et al., unpublished data, 1984). The $\mathrm{P}_{2} \mathrm{O}_{5} / \mathrm{K}_{2} \mathrm{O}$ ratios are probably indicative of mantle source regions [Clague et al., 1981], thus suggesting that lava from region 4 is derived from mantle sources distinct from those of lava from regions $1-3$.

\section{Sample Selection}

A comprehensive sampling and surveying program of the $500-\mathrm{km}$-long ridge segment between the Sovanco and Blanco fracture zones was initiated by the University of Washington in 1980 to characterize the chemical, petrologic, and tectonic interaction among a spreading center of moderate rate, a seamount-generating hotspot, and propagating rifts. Ratios of ${ }^{87} \mathrm{Sr} /{ }^{86} \mathrm{Sr}$ were determined on 39 glass and microcrystallinebasalt samples from 30 locations along the Juan de Fuca Ridge and one sample from the south slope of Brown Bear Seamount. Samples were selected from dredge hauls from cruises 152 and 170 of the R/V T. Thompson (University of Washington) and cruise 81-017 of the R/V Hudson (University of British Columbia). Additional samples were obtained from cruise 74-1 of the R/V Yaquina (Oregon State University) and cruise L1181WF of the R/V S.P. Lee (U.S. Geological Survey). Microprobe analyses of the glass samples analyzed for $\mathrm{Sr}$ isotopes are given in Table 1. Detailed petrography, mineral chemistry, and glass chemistry of a much larger set of samples will be discussed elsewhere (J. R. Delaney et al., unpublished data, 1984). All samples are glassy basalt from the actively spreading axis and were chosen for their freshress and spatial distribution. Samples along the ridge and from the peak of the axial seamount are approximately $25 \mathrm{~km}$ apart.

\section{ANAlytical TeChNiQues}

Hand-picked, fresh glass chips were rinsed in acetone and washed with distilled water in an ultrasonic cleaner for $5 \mathrm{~min}$. Microcrystalline-basalt samples were ground to $<200$ mesh in a tungsten carbide shatterbox. Samples of powder or glass weighing approximately $100 \mathrm{mg}$ were dissolved in $\mathrm{HF}$ and $\mathrm{HClO}_{4}$, and $\mathrm{Sr}$ was separated from the unspiked aliquots using standard ion-exchange chromatography. Mass analysis was done at the U.S. Geological Survey in Menlo Park on a

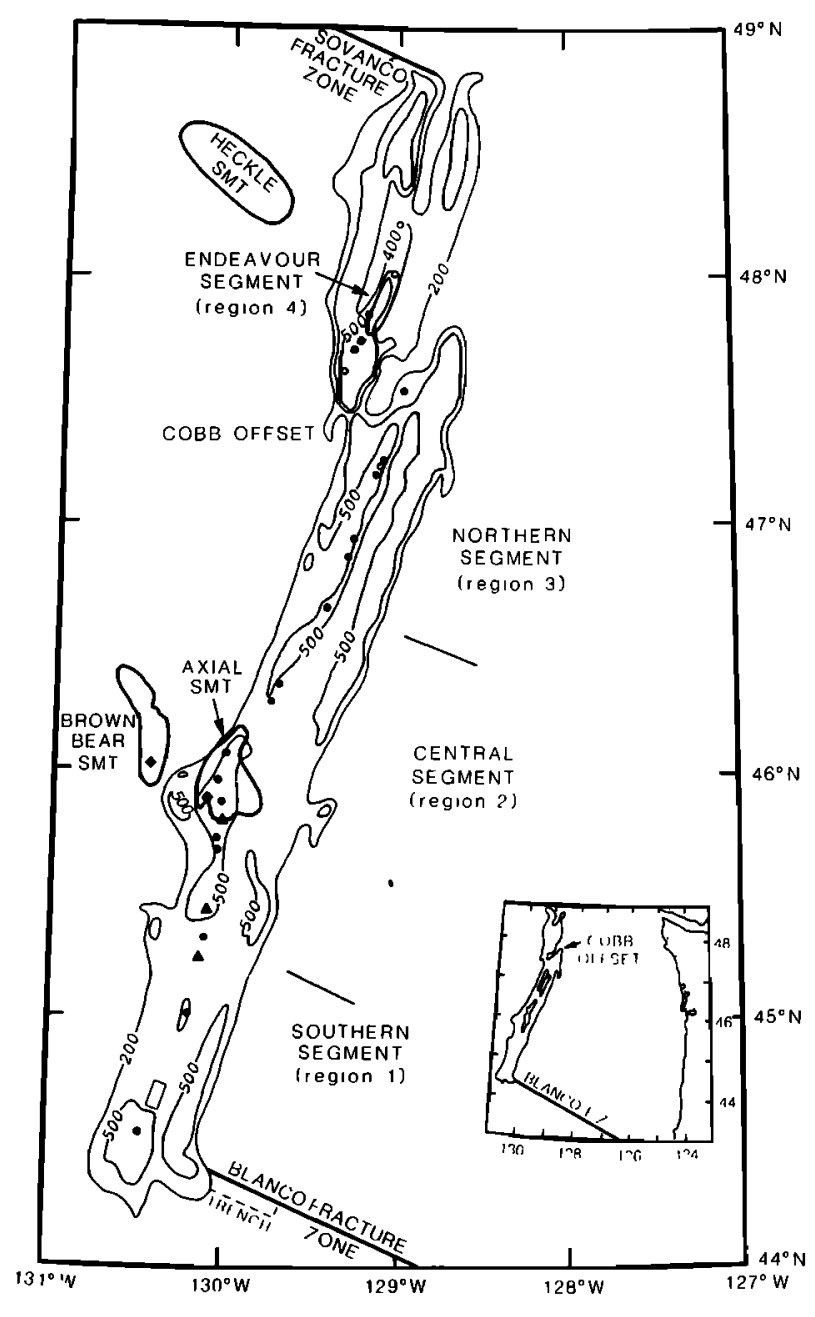

Fig. 2. Locations of dredges sampled for this study. The +200 and $+500 \gamma$ magnetic anomaly contours shown are from National Ocean Survey magnetic anomaly map. Symbols for dredges are solid circles, University of Washington cruise TT152; solid squares, University of Washington cruise TT170; open square, U.S. Geological Survey cruise L1181WF; solid triangles, Oregon State University cruise Y741; and open circles, University of British Colombia cruise HU81-017. Forty samples from 32 dredges were analyzed for ${ }^{87} \mathrm{Sr} /{ }^{86} \mathrm{Sr}$ ratios in this study. Also shown are the divisions between the four morphologically distinct ridge segments, the Cobb offset, and the bathymetric outlines of Cobb and Brown Bear seamounts and the axial seamount (see text for discussion). Figure modified from J. R. Delaney et al. (unpublished data, 1984). 


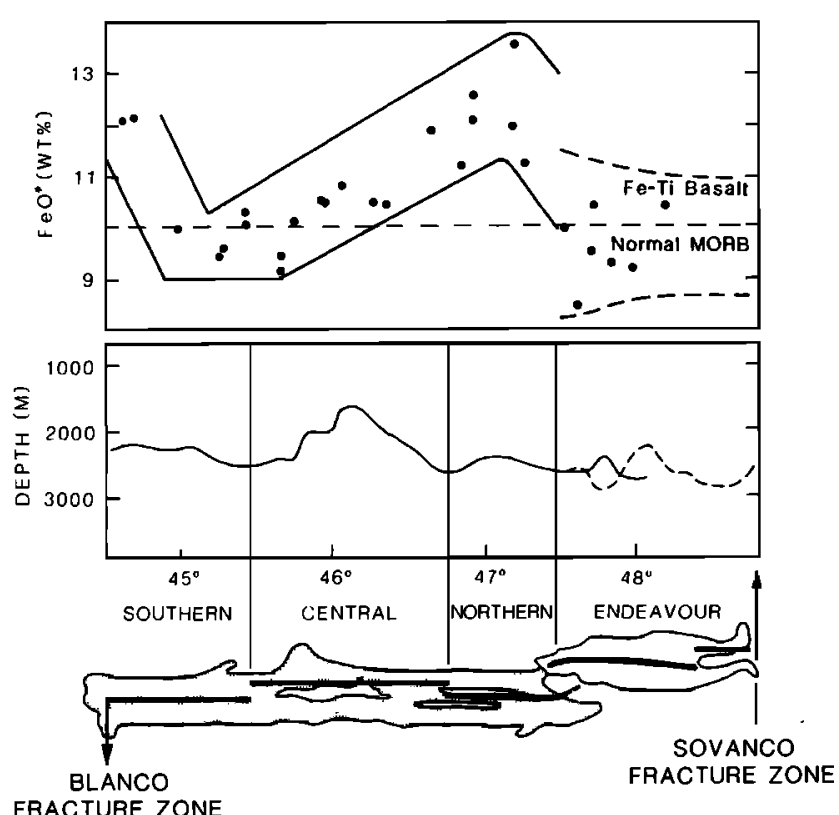

FRACTURE ZONE

Fig. 3. Regional variation of $\mathrm{FeO}^{*}$ content and bathymetry for the Juan de Fuca Ridge. Stippled field surrounds comprehensive data set (J. R. Delaney et al., unpublished data, 1984); FeO* of samples analyzed for ${ }^{87} \mathrm{Sr} /{ }^{86} \mathrm{Sr}$ in this study are shown as solid circles. Bathmetry from the actively spreading axis shows the axial seamount at approximately $46^{\circ} \mathrm{N}$ that is thought to be the most recent activity of the hotspot that produced the Cobb-Eickelberg Seamount chain.

double collector MAT 261 automated spectrometer utilizing a double-filament source. (Any use of trade names and trademarks in this report is for descriptive purposes only and does not constitute endorsement by the U.S. Geological Survey.) Data were collected in 26 mass scans of 85-86-87-88. The data were normalized to a ${ }^{87} \mathrm{Sr} /{ }^{86} \mathrm{Sr}$ ratio of 0.11940 using an exponential mass-fractionation law [Wasserburg et al., 1981] During this study, 35 analyses of the standard SRM 987 SRC03 (National Bureau of Standards) yielded a mean ${ }^{87} \mathrm{Sr} /{ }^{86} \mathrm{Sr}$ ratio of $0.71023 \pm 0.00004(2-\sigma)$. The pooled standard deviations from five replicate analyses provide an estimate of the analytical precision of $\pm 0.00006(2-\sigma)$. More than one sample was analyzed from eight dredge hauls, and the within-dredge mean $2-\sigma$ standard deviation is \pm 0.00008 ; this suggests that intradredge variability is not significantly greater than analytical precision.

The six microcrystalline-basalt samples, though visually unaltered in thin section, were subject to acid leaching in 10 $\mathrm{mL}$ of $2.5 \mathrm{~N} \mathrm{HCl}$ for $10 \mathrm{~min}$. Sr-isotopic composition was measured on both leached and unleached portions; results are shown in Figure 4. Only one leached sample has a ${ }^{87} \mathrm{Sr} /{ }^{86} \mathrm{Sr}$ ratio more than $2-\sigma$ lower than its unleached pair. Though the leaching procedure was not as severe as that described by O'Nions and Pankhurst [1976], the close agreement between analyses of glass and powders of microcrystalline-basalt samples and the very small decrease in ${ }^{87} \mathrm{Sr} /{ }^{86} \mathrm{Sr}$ ratios upon leaching suggest that seawater alteration has not modified the ${ }^{87} \mathrm{Sr} /{ }^{86} \mathrm{Sr}$ ratios of the microcrystalline-basalt samples significantly.

\section{ANAlytical Results}

The measured ${ }^{87} \mathrm{Sr} /{ }^{86} \mathrm{Sr}$ ratios and sample locations are listed in Table 2 and plotted against latitude in Figure 5. In general, the ${ }^{87} \mathrm{Sr} /{ }^{86} \mathrm{Sr}$ ratios are at the lower end of the range for normal MORB and have an average value of
$0.70249 \pm 0.00014(2-\sigma)$. There are subtle variations along strike, but they do not correlate with tectonic or petrologic variations. The results of a probability of statistical difference $(F(z))$ calculation are shown in Table 3. The variations in ${ }^{87} \mathrm{Sr} /{ }^{86} \mathrm{Sr}$ ratios described below were distinguished by eye.

The $\mathrm{Sr}$ isotopic data do not show systematic variation associated with the Cobb Hotspot. The 13 samples that spatially bracket the axial seamount from latitude $45^{\circ}$ to $46^{\circ} 10^{\prime} \mathrm{N}$ (group $b$ ) have essentially uniform $\mathrm{Sr}$ isotopic ratios with an average value of $0.70250 \pm 0.00010(2-\sigma)$. Samples with the lowest ${ }^{87} \mathrm{Sr} /{ }^{86} \mathrm{Sr}$ ratios, $0.70235 \pm 0.00006$, are located on the northern flank of the axial seamount (group $c$ ) and are some of the lowest ratios reported for any MORB [White and Schilling, 1978].

The ${ }^{87} \mathrm{Sr} /{ }^{86} \mathrm{Sr}$ ratios of samples at the southern end of region 1, from the Blanco Fracture Zone to latitude $45^{\circ} \mathrm{N}$ (group $a$ ), are slightly higher than the rest of the ridge; their average value is $0.70260 \pm 0.00009$. This relative maximum is coincident with a high in iron and titanium enrichment. Hedge and Peterman [1970] reported an analysis of $0.7025 \pm 0.0003$ for a sample from this region.

The $\mathrm{Sr}$ isotopic ratios of samples north and south of the Cobb offset (regions 4 and 3; group $d$ ) are statistically identical and have an average value of $0.70246 \pm 0.00009$. The two analyses reported by Hedge and Peterman [1970] for samples from this area have ${ }^{87} \mathrm{Sr} /{ }^{86} \mathrm{Sr}$ ratios of 0.7022 and $0.7025 \pm 0.0003$ and are in agreement with values from this study.

The $\mathrm{Sr}$ isotopic data of lavas from Brown Bear and Cobb seamounts suggest that both normal and enriched type lavas are present. A tholeiite sample from the south slope of Brown Bear Seamount has a ${ }^{87} \mathrm{Sr} /{ }^{86} \mathrm{Sr}$ ratio of $0.70251 \pm 0.00006$ and isotopically resembles the ridge tholeiites. Subbarao et al. [1973] reported ${ }^{87} \mathrm{Sr} /{ }^{86} \mathrm{Sr}$ ratios of three samples from Cobb Seamount. Two lavas that are transitional in composition between alkali basalt and tholeiite have ${ }^{87} \mathrm{Sr} /{ }^{86} \mathrm{Sr}$ ratios of 0.7022 and $0.7023 \pm 0.0005$, typical of a depleted source. In contrast, an alkali basalt has a higher ratio of $0.7033 \pm 0.0002$, indicative of an enriched source. In these samples, unlike the samples along the ridge, ${ }^{87} \mathrm{Sr} /{ }^{86} \mathrm{Sr}$ ratios increase with increasing $\mathrm{K}_{2} \mathrm{O} / \mathrm{K}_{2} \mathrm{O}+\mathrm{Na}_{2} \mathrm{O}$.

\section{Discussion of Results}

The geochemical behavior of the Juan de Fuca Ridge/Cobb Hotspot system is unlike that of other well-studied ridge/hotspot systems. The differences are apparent on plots of ${ }^{87} \mathrm{Sr} /{ }^{86} \mathrm{Sr}$ versus distance from the hotspot (Figure 6) for Iceland, the Azores, the Galapagos spreading center, and the Juan de Fuca Ridge. Hotspots other than the Cobb Hotspot have distinct maxima of $\mathrm{Sr}$ isotopic ratios $(>0.7030)$ that decrease systematically toward ratios more typical of normal MORB (0.7024-0.7030) with increasing distance from the hotspot. Schilling [1982a] and Verma and Schilling [1982] argued that the processes of fractional crystallization, partial melting, or disequilibrium partial melting are inadequate to explain these variations along the Galapagos spreading center, and proposed a binary mixing model between normal and enriched MORB end-members.

In contrast, the geochemical effect of the Cobb Hotspot on the $\mathrm{Sr}$ isotopic ratio of lavas from the Juan de Fuca Ridge is undetectable; there is no systematic spatial variation of ${ }^{87} \mathrm{Sr} /{ }^{86} \mathrm{Sr}$ ratios. By conventional models, the ${ }^{87} \mathrm{Sr} /{ }^{86} \mathrm{Sr}$ ratios of lavas along the ridge suggest that these magmas are derived from an isotopically homogeneous depleted mantle. 


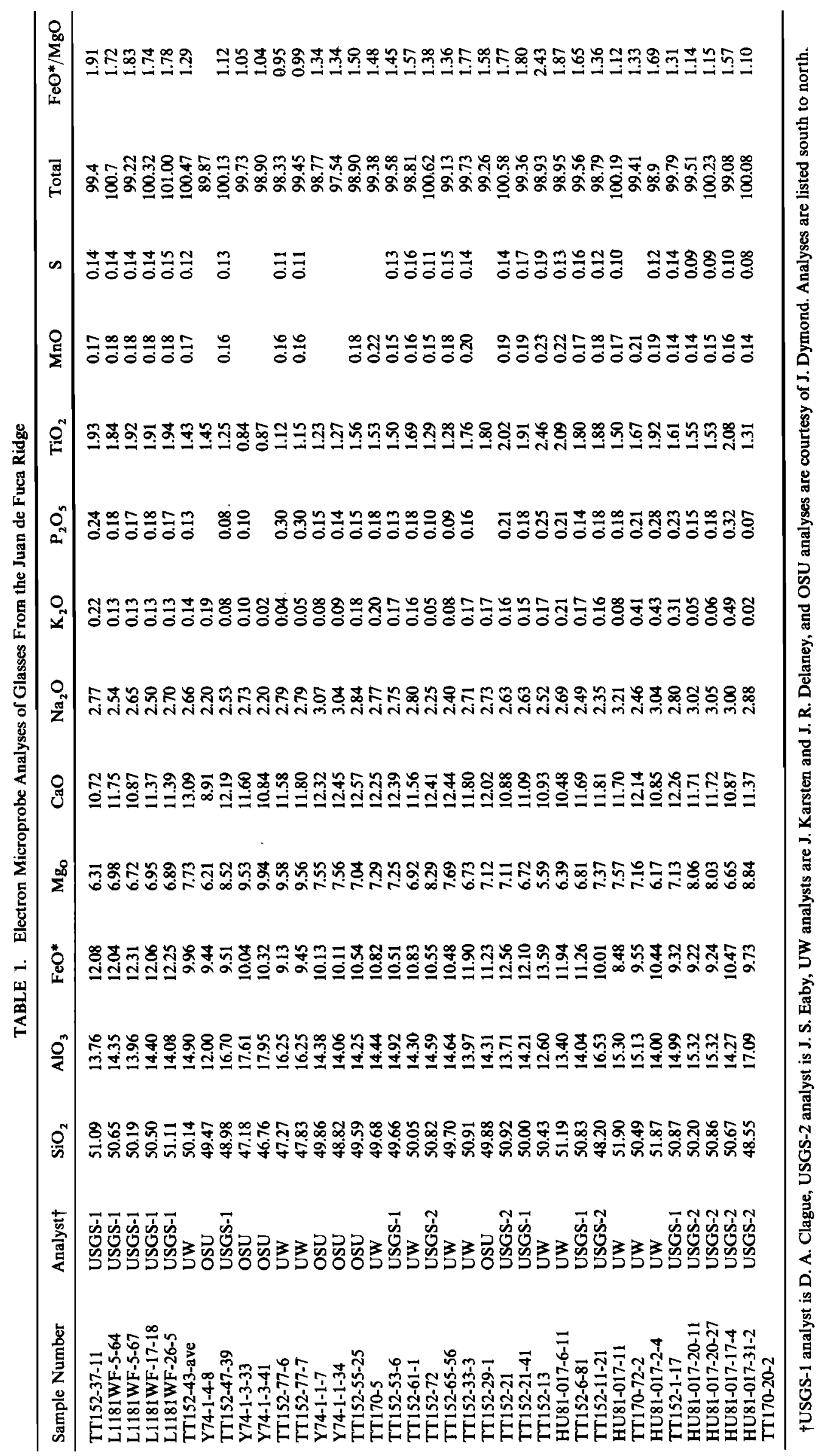




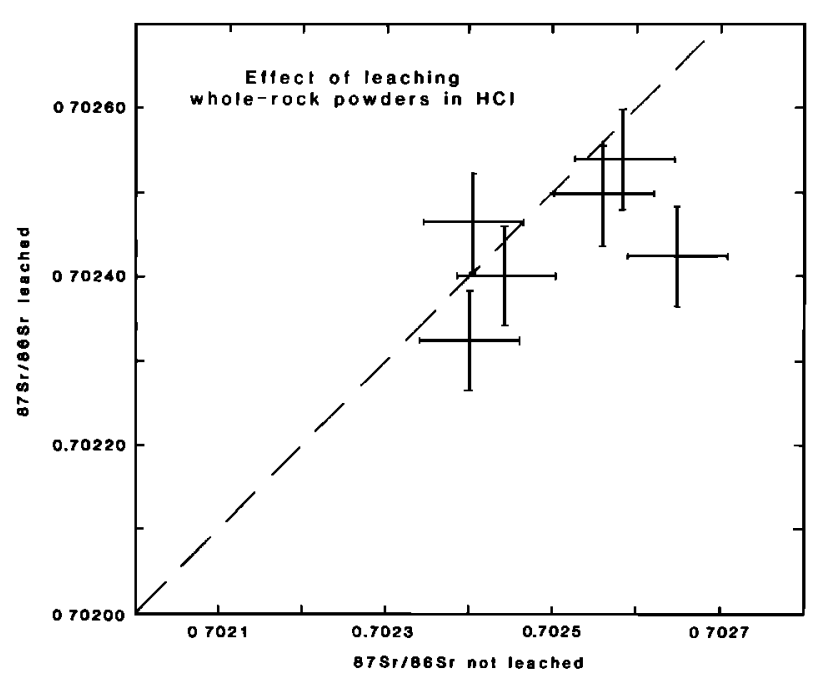

Fig. 4. Plot of ${ }^{87} \mathrm{Sr} /{ }^{86} \mathrm{Sr}$ ratios for leached versus not leached microcrystalline-basalt samples. Dashed line represents line of equality. Only one leached sample has an ${ }^{87} \mathrm{Sr} /{ }^{86} \mathrm{Sr}$ ratio more than $2-\sigma$ lower than its unleached pair.

Trace element data [Liias and Rhodes, 1982; Schilling et al., $1982 b]$ do not show a systematic gradient away from the Cobb Hotspot, thus supporting the conclusion that the hotspot is nonenriched in nature. In contrast to the uniform $\mathrm{Sr}$ isotopic ratios, however, incompatible element ratios are highly variable, both along the whole ridge and within singledredge hauls; most are intermediate between normal and enriched MORB [Liias and Rhodes, 1982]. The rare earth element patterns range from light rare earth element depleted to light rare earth element enriched with a dominance of fairly flat rare earth element patterns.

The higher ${ }^{87} \mathrm{Sr} /{ }^{86} \mathrm{Sr}$ ratios of lavas from the southern end of region 1 could be due to assimilation of hydrothermally altered crust during protracted crystal fractionation [ $O$ 'Hara, 1977] or to subtle mantle heterogeneities. The lack of correlation between $\mathrm{FeO}^{*}$ and ${ }^{87} \mathrm{Sr} /{ }^{86} \mathrm{Sr}$ ratios for lavas along the ridge argues against any simple relation between $\mathrm{Sr}$ isotopic ratios and assimilation during crystal fractionation.

The absence of any variation in $\mathrm{Sr}$ isotopic ratios of lavas from regions 4 and 3 is enigmatic because minor element geochemistry suggests that the lavas were derived from chemically distinct mantle sources (J. R. Delaney et al., unpublished data, 1984). This apparent decoupling could be due to mantle sources that have not been separated long enough to develop isotopic differences.

\section{ImPlications for Mantle Structure}

Debate on the geometry of the chemically defined mantle components is centered around two types of models. In layered-mantle models [Schilling, 1973; Sun and Hanson, 1975; Wasserburg and DePaolo, 1979] a relatively undifferentiated lower mantle (enriched source) is overlain by a more differentiated upper mantle (depleted source). The enriched lower mantle can be introduced into the upper mantle in the form of a rising plume (hotspot). In heterogeneous mantle models [Davis, 1981; Zindler, 1982; Sleep, 1984] the enriched heterogeneities are small and ubiquitously distributed throughout the mantle. Both models implicitly assume that oceanic islands and topographic highs astride ridges are genetically related to the composition of oceanic basalt.

Continued sampling of mid-oceanic ridges is showing that the relation between basalt chemistry and morphotectonic setting is more complex than previously thought. Bryan et al. [1976] report that enriched MORB (their type II) was recovered at ridge segments and Deep Sea Drilling Project (DSDP) drill sites not associated with hotspot-derived oceanic islands or topographic highs. Results from two sites drilled by the International Program of Ocean Drilling (IPOD) Leg 82, designed to test temporal variations of the Azores Hotspot, show that both depleted and enriched MORB occur as intercalated lava flows [Bougault et al., 1983; Weaver and Tarney, 1983]. LeRoex et al. [1983] report that depleted and enriched MORB occur juxtaposed, even within a single dredge, throughout the region, longitude $1^{\circ} \mathrm{W}$ to longitude $11^{\circ} \mathrm{E}$, along the Southwest Indian Ridge, an extremely slowly spreading ridge. They also find no evidence for a geochemical gradient away from the Bouvet Hotspot. The spatial and temporal juxtaposition of enriched and depleted MORB suggests that the mantle sources are heterogeneous on the scale of kilometers to tens of kilometers. The absence of geochemical gradients away from the Cobb and Bouvet hotspots suggests that the high volcanic productivity may be caused by thermal anomalies in the mantle rather than by enriched mantle plumes.

Results from studies of small seamounts are consistent with a model of ubiquitous small heterogeneities in the mantle. In a study of relatively small, isolated, oceanic central volcanoes on young crust near the East Pacific Rise, Batiza [1980] showed that most volcanoes are composed of basalt chemically similar to MORB. Some young volcanoes contain both depleted and enriched basalt; compositional diversity seems to increase with lithosphere age [Batiza and Vanko, 1984]. Seamounts in the northeast Pacific including Denson, Davidson, and Hodgkins seamounts of the Pratt-Welker chain [Turner et al., 1980] and the Heck and Heckle seamount chains [Barr, 1974] are interpreted to have erupted on or near a spreading center and are similar in major and minor element compositions to normal MORB. No $\mathrm{Sr}$ isotopic data for these seamounts are available for comparison. The ${ }^{87} \mathrm{Sr} /{ }^{86} \mathrm{Sr}$ ratios from Cobb and Brown Bear seamounts and the axial seamount suggest that central volcanoes on or near the Juan de Fuca Ridge are constructed of lavas derived from depleted sources. The CobbEickelberg seamount chain is intermediate in size between the small volcanoes studied by Batiza and the large hotspotgenerated islands of Hawaii, Iceland, and Galapagos. The occurrence of both depleted and enriched basalt on Cobb Seamount indicates that enriched magma may be tapped as the volcano moves farther away from the ridge axis.

Simple heterogeneous mantle models, however, cannot explain the dominance of depleted compositions produced at mid-oceanic ridge spreading centers; production of basaltic melt from a mantle source with ubiquitous small heterogeneities should result in a wide range of compositions distributed randomly along mid-oceanic ridges. Cohen and O'Nions [1982] and Allegre et al. [1983] suggest that spreading rate is an important variable controlling the extent or compositional variability of lava along a given spreading center. Homogenization of melt compositions will occur at fast spreading ridges, such as the East Pacific Rise, because multiple batches of magma will mix in extensive magma chambers. Transient magma chambers along slow spreading ridges, such as the Southwest Indian and Mid-Atlantic Ridges, allow for the eruption of single batches of magma with compositions more representative of mantle sources. The small range of $\mathrm{Sr}$ isotopic ratios of basalt from the Juan de Fuca Ridge may be 
TABLE 2. Sr Isotope Analyses of Basalt From the Juan de Fuca Ridge

\begin{tabular}{|c|c|c|c|c|c|c|}
\hline $\begin{array}{l}\text { Sample } \\
\text { Number }\end{array}$ & Source* & Regiont & $\begin{array}{l}\text { Latitude, } \\
\text { deg north }\end{array}$ & $\begin{array}{l}\text { Longitude, } \\
\text { deg west }\end{array}$ & $\begin{array}{l}\text { Depth, } \\
\text { m }\end{array}$ & ${ }^{87} \mathrm{Sr} /{ }^{86} \mathrm{Sr}$ \\
\hline TT152-37 & 1 & 1 & $44^{\circ} 37.1^{\prime}$ & $130^{\circ} 23.4^{\prime}$ & $2235-2240$ & 0.70261 \\
\hline TT152-37-11 & 1 & 1 & $44^{\circ} 37.1^{\prime}$ & $130^{\circ} 23.4^{\prime}$ & $2235-2240$ & 0.70255 \\
\hline L1181WF-5-64 & 4 & 1 & $44^{\circ} 38.37^{\prime}$ & $130^{\circ} 22.60^{\prime}$ & 2208 & 0.70259 \\
\hline L1181WF-5-67 & 4 & 1 & $44^{\circ} 38.37^{\prime}$ & $130^{\circ} 22.60^{\prime}$ & 2208 & 0.70267 \\
\hline L1181WF-17-18 & 4 & 1 & $44^{\circ} 39.33^{\prime}$ & $130^{\circ} 21.98^{\prime}$ & 2231 & 0.70256 \\
\hline L1181WF-26-5 & 4 & 1 & $44^{\circ} 42.07^{\prime}$ & $130^{\circ} 20.72^{\prime}$ & 2228 & 0.70257 \\
\hline TT152-43-19 & 1 & 1 & $44^{\circ} 59.6^{\prime}$ & $130^{\circ} 12.3^{\prime}$ & 2282 & 0.70263 \\
\hline Y74-1-4-8 & 3 & 1 & $45^{\circ} 16^{\prime}$ & $130^{\circ} 08^{\prime}$ & 2400 & 0.70241 \\
\hline TT152-47-39 & 2 & 1 & $45^{\circ} 17.7^{\prime}$ & $130^{\circ} 05.2^{\prime}$ & $2400-2450$ & 0.70254 \\
\hline Y74-1-3-33 & 3 & 1 & $45^{\circ} 27^{\prime}$ & $130^{\circ} 08^{\prime}$ & 1250 & 0.70253 \\
\hline Y74-1-3-41 & 3 & 1 & $45^{\circ} 27^{\prime}$ & $130^{\circ} 08^{\prime}$ & 1250 & 0.70256 \\
\hline TT152-77-6 & 1 & 2 & $45^{\circ} 40.3^{\prime}$ & $130^{\circ} 03.8^{\prime}$ & $1920-2060$ & 0.70244 \\
\hline TT152-77-7 & 1 & 2 & $45^{\circ} 40.3^{\prime}$ & $130^{\circ} 03.8^{\prime}$ & $1920-2060$ & 0.70252 \\
\hline TT152-50-25 & 2 & 2 & $45^{\circ} 42.5^{\prime}$ & $130^{\circ} 02.5^{\prime}$ & 2100 & 0.70256 \\
\hline Y74-1-1-7 & 3 & 2 & $45^{\circ} 46^{\prime}$ & $130^{\circ} 01^{\prime}$ & 2169 & 0.70245 \\
\hline Y74-1-1-34 & 3 & 2 & $45^{\circ} 46^{\prime}$ & $130^{\circ} 01^{\prime}$ & 2169 & 0.70252 \\
\hline TT152-55-25 & 1 & 2 & $45^{\circ} 56.3^{\prime}$ & $129^{\circ} 59.6^{\prime}$ & $1530-1557$ & 0.70257 \\
\hline TT170-5 & 1 & 2 & $45^{\circ} 56.9^{\prime}$ & $130^{\circ} 01.8$ & $1425-1560$ & 0.70246 \\
\hline TT152-53-6 & 2 & 2 & $45^{\circ} 57.7^{\prime}$ & $130^{\circ} 03.3^{\prime}$ & $1460-1510$ & 0.70250 \\
\hline TT152-61-1 & 1 & 2 & $46^{\circ} 04.5^{\prime}$ & $129^{\circ} 58.08^{\prime}$ & 2215-2355 & 0.70249 \\
\hline TT152-72 & 1 & 2 & $46^{\circ} 16.7^{\prime}$ & $129^{\circ} 43.8^{\prime}$ & $2265-2366$ & 0.70237 \\
\hline TT152-65-56 & 2 & 2 & $46^{\circ} 21.2^{\prime}$ & $129^{\circ} 40.7^{\prime}$ & $2295-2320$ & 0.70233 \\
\hline TT152-33-3 & $i$ & 3 & $46^{\circ} 39.2^{\prime}$ & $129^{\circ} 25.6^{\prime}$ & $2425-2511$ & 0.70245 \\
\hline TT152-29-1 & 1 & 3 & $46^{\circ} 51.6^{\prime}$ & $129^{\circ} 17.9^{\prime}$ & $2310-2360$ & 0.70243 \\
\hline TT152-21 & 1 & 3 & $46^{\circ} 55.5^{\prime}$ & $129^{\circ} 15.7^{\prime}$ & $2410-2520$ & 0.70248 \\
\hline TT152-21-41 & 2 & 3 & $46^{\circ} 55.5^{\prime}$ & $129^{\circ} 15.7^{\prime}$ & $2410-2520$ & 0.70246 \\
\hline TT152-13 & $\overrightarrow{1}$ & 3 & $47^{\circ} 12.5^{\prime}$ & $129^{\circ} 07.2^{\prime}$ & 2625 & 0.70243 \\
\hline HU81-017-6-11 & 1 & 3 & $47^{\circ} 12.6^{\prime}$ & $129^{\circ} 04.87^{\prime}$ & 2600 & 0.70245 \\
\hline TT152-6-81 & 2 & 3 & $47^{\circ} 16.1^{\prime}$ & $129^{\circ} 04.1^{\prime}$ & 2575 & 9.70240 \\
\hline TT152-11-21 & 1 & 3 & $47^{\circ} 32.5^{\prime}$ & $128^{\circ} 57.8^{\prime}$ & $2640-2690$ & 0.70247 \\
\hline HU81-017-11 & 1 & 3 & $47^{\circ} 37.21^{\prime}$ & $129^{\circ} 17.31^{\prime}$ & 1390 & 0.70254 \\
\hline TT170-72-2 & 1 & 4 & $47^{\circ} 42.49^{\prime}$ & $129^{\circ} 16.55^{\prime}$ & 2700 & 0.70259 \\
\hline HU81-017-2-4 & 1 & 4 & $47^{\circ} 43.6^{\prime}$ & $129^{\circ} 14.8^{\prime}$ & 2600 & 0.70241 \\
\hline TT152-1-17 & 2 & 4 & $47^{\circ} 50.7^{\prime}$ & $129^{\circ} 09.3^{\prime}$ & 2440 & 0.70243 \\
\hline HU81-017-20-11 & 1 & 4 & $47^{\circ} 59.9^{\prime}$ & $128^{\circ} 59.4^{\prime}$ & 2125 & 0.70250 \\
\hline HU81-017-20-21 & 1 & 4 & $47^{\circ} 59.9^{\prime}$ & $128^{\circ} 59.4^{\prime}$ & 2125 & 0.70243 \\
\hline HU81-017-20-27 & 1 & 4 & $47^{\circ} 59.9^{\prime}$ & $128^{\circ} 59.4^{\prime}$ & 2125 & 0.70243 \\
\hline HU81-017-17-4 & 1 & 4 & $48^{\circ} 12.0^{\prime}$ & $128^{\circ} 58.9^{\prime}$ & 2615 & 0.70250 \\
\hline HU81-017-31-2 & $i$ & 4 & $49^{\circ} 03.3^{\prime}$ & $130^{\circ} 56.7^{\prime}$ & 1200 & 0.70241 \\
\hline TT170-20-2 & 1 & BBS & $45^{\circ} 59.76^{\prime}$ & $130^{\circ} 25.73^{\prime}$ & 2100 & 0.70251 \\
\hline
\end{tabular}

Sample HU81-017-31-2 is from Explorer Seamount and is not shown on the figures. Estimated analytical precision for ${ }^{87} \mathrm{Sr} /{ }^{86} \mathrm{Sr}$ analyses is \pm 0.00006 .

*Source codes are 1, UW glass; 2, UW microcrystalline-basalt; 3, OSU glass; 4, U.S. Geological Survey microcrystalline-basalt.

†Region codes are 1 , latitude $44^{\circ} 30^{\prime}-45^{\circ} 28^{\prime} \mathrm{N}$; 2, latitude $45^{\circ} 28^{\prime}-46^{\circ} 39^{\prime} \mathrm{N}$; 3, latitude $46^{\circ} 39^{\prime}-47^{\circ} 40^{\prime} \mathrm{N}$; 4, > latitude $47^{\circ} 40^{\prime} \mathrm{N}$; BBS, Brown Bear Seamount.

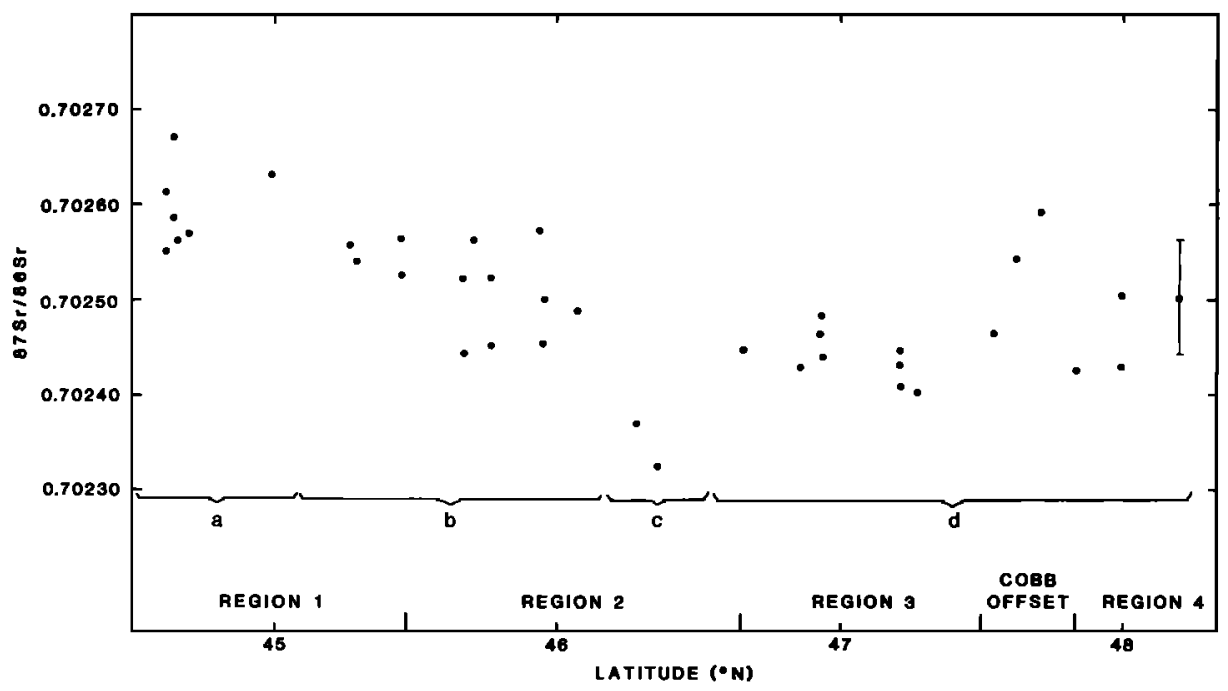

Fig. 5. Regional variation of ${ }^{87} \mathrm{Sr} /{ }^{86} \mathrm{Sr}$ ratios. A sample $2-\sigma$ error bar is shown on the right-hand side of the figure. The Sr isotopic data do not show systematic variation relative to the Cobb Hotspot. 
TABLE 3. Data Used for Calculation of the Probability of Statistical Difference

\begin{tabular}{clc}
\hline Group & \multicolumn{1}{c}{ Location } & Mean ${ }^{87} \mathrm{Sr} /{ }^{86} \mathrm{Sr}$ \\
\hline$a$ & Southern tip of region 1 & $0.70260 \pm 9$ \\
$b$ & $\begin{array}{c}\text { Spatially bracketing the } \\
\text { axial seamount }\end{array}$ & $0.70252 \pm 14$ \\
$c$ & $\begin{array}{c}\text { Lowest ratios; northern } \\
\text { flank of axial seamount }\end{array}$ & $0.70235 \pm 6$ \\
$d$ & Regions 3 and 4 & $0.70246 \pm 9$ \\
\hline
\end{tabular}

For the data pair of $a-b$, probability is 0.47 ; for $a-c, 0.98$; for $a-d$, 0.73; for $b-c, 0.88$; for $b-d, 0.36$; and for $c-d, 0.69$.

caused by averaging of heterogeneous magma batches by mixing in long-lived magma chambers. Mixing of relatively undifferentiated magmas and residual differentiates in longlived magma chambers that are periodically replenished is indicated by mineral compositional data [Clague et al., 1983]. The Juan de Fuca data imply that the depleted mantle source end-member has a ${ }^{87} \mathrm{Sr} /{ }^{86} \mathrm{Sr}$ ratio less than 0.70235 .

Sleep [1984] has proposed a model using mantle convection dynamics in a heterogeneous mantle that offers an explanation for the formation of depleted mantle sources for MORB and enriched mantle sources farther away from the spreading axis. Sleep argues that the direction of shear stress in the upwelling mantle diapir is such that the axis of tension plunges away from the ridge at great depths and is nearly vertical at shallow levels. Enriched heterogeneities melt preferentially in comparison with the surrounding mantle. At great depths, these early enriched melts enter fractures that carry them away from the ridge axis. The residual mantle diapir would be depleted relative to the average mantle, owing to melting events early in the earth's history and to loss of the early enriched melts, and would give rise to depleted MORB upon partial melting at shallow levels.

Sleep's model also addresses the dependence of large ion lithophile enrichment of hotspot magmas on (1) the size of the heterogeneities, (2) the total volume of enriched material originally present in the mantle, and (3) the efficiencies of melting and melt removal during ascent of a mantle diapir. The source region for the Juan de Fuca Ridge and the Cobb Hotspot, according to Sleep's model, would be almost completely stripped of enriched melts before reaching shallow levels. Small volumes of enriched melt are more likely to be tapped as seamounts move off axis than at normal ridge segments. Tapping of melts from somewhat greater depths at slow spreading ridges than at fast ridges, or diversion of enriched magma back into the ridge along fractures are two possible explanations for the chemical enrichments exhibited by the other hotspots such as Iceland, the Azores, and the Galapagos spreading center.

\section{Conclusions}

A systematic $\mathrm{Sr}$ isotopic gradient does not exist along the Juan de Fuca Ridge away from the Cobb Hotspot. There is no evidence to support a model in which an enriched mantle plume is responsible for the zone of high volcanic productivity building the axial seamount. The small range in $\mathrm{Sr}$ isotopic ratios along the Juan de Fuca Ridge may be related to homogenization by mixing in long-lived magma chambers as suggested by Cohen and $O$ 'Nions [1982] or Allegre et al. [1983] or to lateral migration away from the ridge axis of enriched melts generated at greater depths as proposed by Sleep [1984]. $\mathrm{Sr}$ isotopic ratios of samples north and south of the Cobb offset are identical. The decoupling of minor element and isotopic compositions suggests that the source region heterogeneities formed recently.

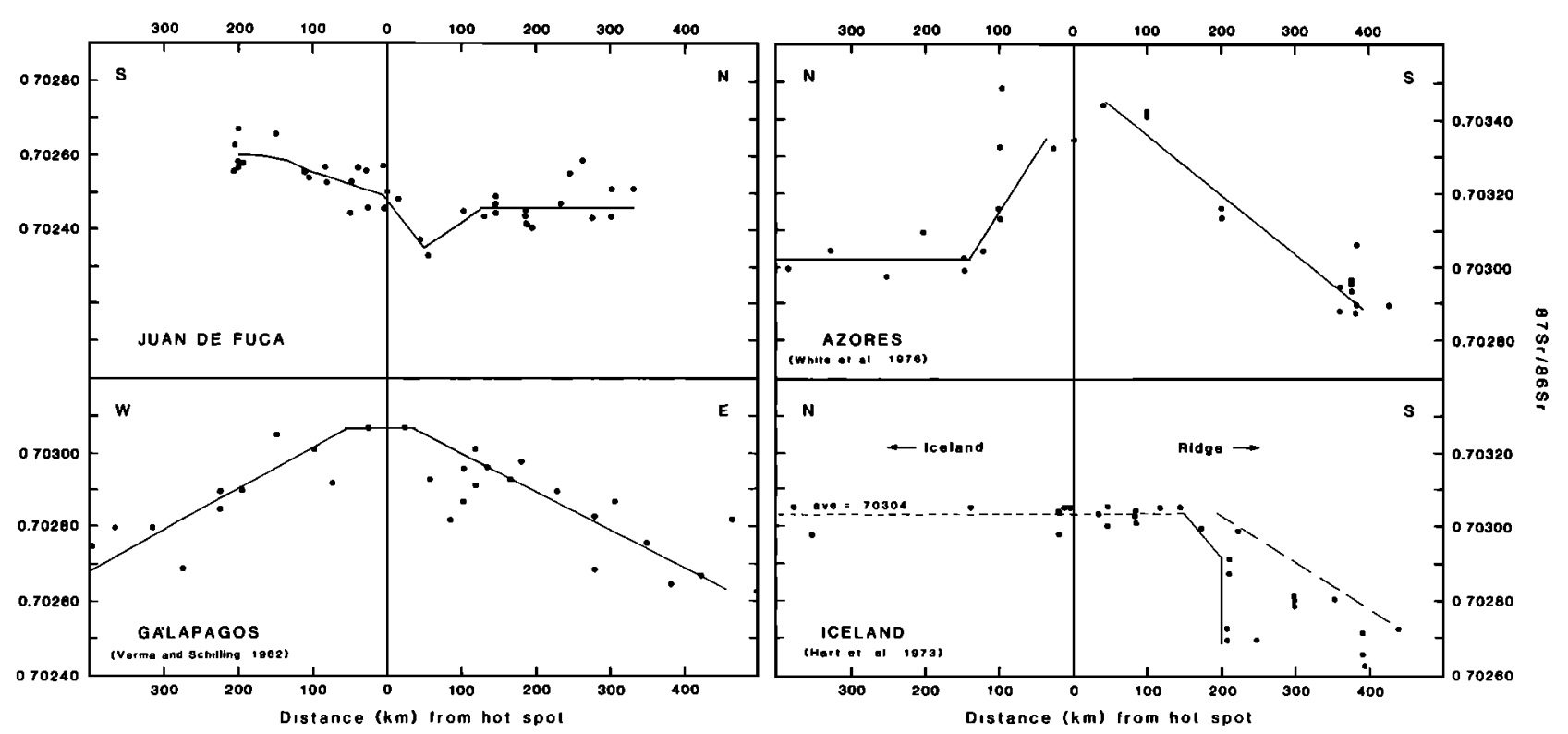

Fig. 6. ${ }^{87} \mathrm{Sr} /{ }^{86} \mathrm{Sr}$ ratios versus distance from hotspot for Iceland [Hart et al., 1973], the Azores [White et al., 1976], the Galapagos spreading center [Verma and Schilling, 1982], and Juan de Fuca Ridge. Unlike Sr isotopic ratios from Juan de Fuca Ridge, $\mathrm{S} r$ isotopic ratios from Iceland, Azores, and Galapagos spreading center have distinct maxima $(>0.7030)$ at the hotspot that decrease systematically toward ratios more typical of normal MORB with increasing distance from the hotspot. 
Acknowledgments. We express our appreciation to Debbie Kelley for hand picking the glass samples, Jack Dymond for supplying samples from OSU, and Anne Tapay for operating the mass spectrometer. Thorough reviews by Marvin Lanphere, Robert Christiansen, JeanGuy Schilling, and Rodey Batiza greatly improved the manuscript. Some of the ideas are the result of discussions with Norm Sleep, Gail Mahood, Clark Johnson, Jan Morton, John Lupton, Roger Hart, and Jack Dymond. This project was supported in part by NSF grant OCE81-11413.

\section{REFERENCES}

Allegre, C. J., B. Dupre, and B. Hamelin, Geochemistry of oceanic ridge basalts explained by blob mantle mixing, Eos Trans. $A G U$, $64,324,1983$.

Barr, S. M., Seamount chains formed near the crest of the Juan de Fuca Ridge, northeast Pacific Ocean, Mar. Geol., 17, 1-19, 1974.

Batiza, R., Origin and petrology of young oceanic central volcanoes: Are most tholeiitic rather than alkalic?, Geology, 8, 477-482, 1980.

Batiza, R., and D. Vanko, Petrology of young Pacific seamounts, $J$. Geophys. Res., in press, 1984.

Bougault, H., S. Cande, J. L. Joron, and M. Treuil, Local versus regional mantle heterogeneities: IPOD Leg 82 of the Glomar Challenger, Eos Trans. AGU, 64, 345, 1983.

Bryan, W. B., G. Thompson, F. A. Frey, and J. S. Dickey, Inferred geologic settings and differentiation in basalts from the Deep-Sea Drilling Project, J. Geophys. Res., 81, 4285-4304, 1976.

Clague, D. A., and T. E. Bunch, Formation of ferrobasalt at East Pacific midocean spreading centers, J. Geophys. Res., 81, 42474256, 1976 .

Clague, D. A., F. A. Frey, G. Thompson, and S. Rindge, Minor and trace element geochemistry of volcanic rocks dredged from the $\mathbf{G a}$ lapagos spreading center: Role of crystal fractionation and mantle heterogeneity, J. Geophys. Res., 86, 9469-9482, 1981.

Clague, D. A., J. S. Eaby, and J. R. Delaney, Petrologic evidence for long-lived axial magma chambers on the Juan de Fuca Ridge (abstract), paper presented at the Fifth Annual Geodynamics Research Symposium on Oceanic Lithosphere: Origin, Structure, and Dynamics, Texas A\&M University, 1983.

Cohen, R. S., and R. K. O'Nions, The lead, neodymium and strontium isotopic structure of ocean ridge basalts, J. Petrol, 23, 299$324,1982$.

Davies, G. F., Earth's neodymium budget and structure and evolution of the mantle, Nature, 290, 208, 1981.

Delaney, J. R., H. P. Johnson, and J. L. Karsten, The Juan de Fuca Ridge-hotspot-propagating rift system: New tectonic, geochemical, and magnetic data, J. Geophys. Res., 86, 11747-11750, 1981.

Delaney, J. R., J. L. Karsten, and D. A. Clague, Geochemistry of Juan de Fuca Ridge basaltic glasses, Eos Trans. AGU, 63, 1147, 1982.

DePaolo, D. J., and G. J. Wasserburg, Inferences about magma sources and mantle structure from variations of ${ }^{143} \mathrm{Nd} /{ }^{144} \mathrm{Nd}$, Geophys. Res. Lett., 3, 743-746, 1976.

Hart, S. R., J.-G. Schilling, and J. L. Powell, Basalts from Iceland and along the Reykjanes Ridge: $\mathrm{Sr}$ isotope geochemistry, Nature Phys. Sci., 246(155), 104-107, 1973.

Hedge, C. E., and Z. E. Peterman, The strontium isotope composition of basalts from the Gordo and Juan de Fuca Rises, northeastern Pacific Ocean, Contrib. Mineral. Petrol., 27, 114-120, 1970.

Hey, R. N., and D. S. Wilson, Propagating rift explanation for the tectonic evolution of the northeast Pacific-The pseudomovie, Earth Planet. Sci. Lett., 58, 167-188, 1982.

Johnson, H. P., J. L. Karsten, J. R. Delaney, E. E. Davies, R. G. Currie, and R. L. Chase, A detailed study of the Cobb Offset of the Juan de Fuca Ridge: Evolution of a propagating rift, J. Geophys. Res., 88, 2297-2315, 1983.

Kay, R., N. J. Hubbard, and P. W. Gast, Chemical characteristics and origin of oceanic ridge volcanic rocks, J. Geophys. Res., 75, 1585$1613,1970$.

LeRoex, A. P., H. J. B. Dick, A. J. Erlank, A. M. Reid, F. A. Frey, and S. R. Hart, Geochemistry, mineralogy and petrogenesis of lavas erupted along the southwest Indian ridge between the Bouvet triple junction and 11 degrees East, J. Petrol., 24, 267-318, 1983.

Liias, R. A., and J. M. Rhodes, Evolution of basaltic magma along the Juan de Fuca Ridge, Eos Trans. AGU, 63, 1147, 1982.

Morgan, W. J., Plate motions and deep mantle convection, in Studies in Earth and Space Sciences, Hess Volume, Mem. 132, edited by R. Shagan et al., Geological Society of America, Boulder, Colo., 1973.

O'Hara, M. J., Geochemical evolution during fractional crystallisation of a periodically refilled magma chamber, Nature, 266, 503$508,1977$.
O'Nions, R. K., and R. J. Pankhurst, Sr isotope and rare earth element geochemistry of DSDP Leg 37 basalts, Earth Planet. Sci. Lett., 31, 255-261, 1976.

O'Nions, R. K., P. J. Hamilton, and N. M. Evensen, Variations in ${ }^{143} \mathrm{Nd} /{ }^{144} \mathrm{Nd}$ and ${ }^{87} \mathrm{Sr} /{ }^{86} \mathrm{Sr}$ ratios in oceanic basalts, Earth Planet. Sci. Lett., 34, 13-22, 1977.

Schilling, J.-G., Iceland mantle plume geochemical evidence along Reykjanes Ridge, Nature, 242, 565-571, 1973.

Schilling, J.-G., Rare-earth variations across "normal" segements of the Reykjanes Ridge, $60^{\circ}-53^{\circ} \mathrm{N}$, Mid-Atlantic Ridge, $29^{\circ} \mathrm{S}$, and East Pacific Rise, $2^{\circ}-19^{\circ} \mathrm{S}$, and evidence on the composition of the underlying low velocity layer, J. Geophys. Res., 80, 1459-1473, $1975 a$.

Schilling, J.-G., Azores mantle blob: Rare earth evidence, Earth Planet. Sci. Lett., 25, 103-115, $1975 b$.

Schilling, J.-G., R. Kingsley, and J. Devine, Galapagos hot spotspreading center system, 1, Spatial petrological and geochemical variations $\left(83^{\circ} \mathrm{W}-101^{\circ} \mathrm{W}\right)$, J. Geophys. Res., 87, 5593-5610, $1982 a$.

Schilling, J.-G., B. Cousens, R. L. Chase, and J. R. Delaney, Juan de Fuca-Explorer Ridge: Rare earth contents, Eos Trans. AGU, 63, $1154,1982 b$.

Sinton, J. M., D. S. Wilson, D. M. Christie, R. N. Hey, and J. R. Delaney, Petrologic consequences of rift propagation on oceanic spreading ridges, Earth Planet. Sci. Lett., 62, 193-207, 1983.

Sleep, N. H., Tapping of magmas from ubiquitous mantle heterogeneities, $J$. Geophys. Res., in press, 1984.

Subbarao, K. V., G. S. Clark, and R. B. Forbes, Strontium isotopes in some seamount basalts from the northeastern Pacific ocean, Can. J. Earth Sci., 10, 1479, 1973.

Sun, S. S., and G. N. Hanson, Evolution of the mantle: Geochemical evidence from alkali basalt, Geology, 3, 297-302, 1975.

Turner, D. L., R. D. Jarrard, and R. B. Forbes, Geochronology and origin of the Pratt-Welker Seamount Chain, Gulf of Alaska: A new pole of rotation for the Pacific Plate, J. Geophys. Res., 85, 65476556,1980

Verma, S. P., and J.-G. Schilling, Galapagos hot spot-spreading center system, $2,{ }^{87} \mathrm{Sr} /{ }^{86} \mathrm{Sr}$ and large ion lithophile element variations $\left(85^{\circ} \mathrm{W}-101^{\circ} \mathrm{W}\right)$, J. Geophys. Res., 87, 10838-10856, 1982.

Vogt, P. R., and G. R. Byerly, Magnetic anomalies and basalt composition in the Juan de Fuca-Gorda Ridge area, Earth Planet. Sci. Lett., 33, 185-207, 1976.

Vogt, P. R., and G. L. Johnson, Transform faults and longitudinal flow below the midoceanic ridge, J. Geophys. Res., 80, 1399-1428, 1975.

Wasserburg, G. J., and D. J. DePaolo, Models of earth structure inferred from neodymium and strontium isotopic abundances, Proc. Nat. Acad. Sci., 76(8), 3594-3598, 1979.

Wasserburg, G. J., S. B. Jacobsen, D. J. DePaolo, M. T. McCulloch, and T. Wen, Precise determination of $\mathrm{Sm} / \mathrm{Nd}$ ratios, $\mathrm{Sm}$ and $\mathrm{Nd}$ isotopic abundance in standard solution, Geochim. Cosmochim. Acta, 45, 2311-2324, 1981.

Weaver, B. L., and J. Tarney, Trace element geochemistry of basalts recovered by DSDP Leg 82: Implications for mantle heterogeneity, Eos Trans. AGU, 64, 345, 1983.

White, W. M., and W. B. Bryan, Sr-isotope, K, Rb, Cs, Sr, Ba, and rare-earth geochemistry of basalts from the FAMOUS area, Geol. Soc. Am. Bull., 88, 571-576, 1977.

White, W. M., and J.-G. Schilling, The nature and origin of geochemical variations in Mid-Atlantic Ridge basalts from the central North Atlantic, Geochim. Cosmochim. Acta., 42, 1501-1516, 1978.

White, W. M., S. R. Hart, and J.-G. Schilling, Geochemistry of the Azores and the Mid-atlantic Ridge: $29^{\circ} \mathrm{N}$ to $60^{\circ} \mathrm{N}$, Carnegie Inst. Wash. Yearb., 74, 224-234, 1975.

White, W. M., J.-G. Schilling, and S. R. Hart, Evidence for the Azores mantle plume from strontium isotope geochemistry of the central north Atlantic, Nature, 263, 659-663, 1976.

Wilson, J. T., Evidence from ocean islands suggesting movement in the earth, Phil. Trans. R. Soc. London, 258, 145-165, 1965.

Zindler, A., E. Jagoutz, and S. Goldstein, Nd, $\mathrm{Sr}$ and $\mathrm{Pb}$ isotopic systematics in a three-component mantle: A new perspective, Nature, 298, 519, 1982.

D. A. Clague and J. Eaby, U.S. Geological Survey, MS 999, 345 Middlefield Road, Menlo Park, CA 94025.

J. R. Delaney, Oceanography Department, WB-10, University of Washington, Seattle, WA 98195.

(Received November 11, 1983; revised April 30, 1984; accepted May 8, 1984.) 